\title{
钢铁工业废气中重金属及棩化物通过大气沉降对土壤的影响规律 研究
}

赵雪 蔡淑芬

吉林省春光环保科技有限公司

DOI:10.32629/eep.v2i10.502

[摘要] 我国钢铁行业在不断发展的同时,也带来了废气污染物的排放对周围环境造成一定影响,尽管近些年已对废气进行了有效的治理并得 到了显著成效,但过去的几十年中,对土壤的影响则是累积的,因此,需要对其影响规律进行研究, 以便因地制宜,合理利用,必要时采取修复措施。 [关键词] 重金属; 氟化物; 土壤; 钢铁

\section{引言}

近十年, 随着经济的发展转型, 环保技术的进步及环保管理、排放标准 的严格, 钢铁行业废气、废水的污染防治措施日趋完善, 处理效率明显提高, 特别是厂界无组织排放显著改善, 粉尘沉降影响也有所减轻, 废水废气的 达标排放已不成问题。对周围的大气和水体环境影响也越来越小。

然而, 过去的几十年, 对于大气和水体的影响已稀释扩散不明显, 但土 壤的污染影响却是累积的。

\section{1 钢铁行业周围土壤环境现状调查}

在被调查钢铁厂厂区及常年主导风向下风向选择布设监测点位。共布 设 122 个采样点, 分别为主要污染装置附近, 堆场附近, 厂界及周围, 下风向 $500 \mathrm{~m}, 1000 \mathrm{~m}, 1500 \mathrm{~m}, 2000 \mathrm{~m}, 2500 \mathrm{~m}$ 。采用频次为 1 次/年。采取时间上对监测 期间取平均值方法进行分析。

\section{2 土壤环境中污染物的规律}

\section{1 重金属}

重金属在厂区内的规律为: 烧结, 焦化及污水处理站附近含量较厂区 其他装置附近的监测点位的重金属高2-3倍; 厂外土壤中重金属含量规律 为: 下风向1500-2500m范围监测点位的重金属较厂区周边高。
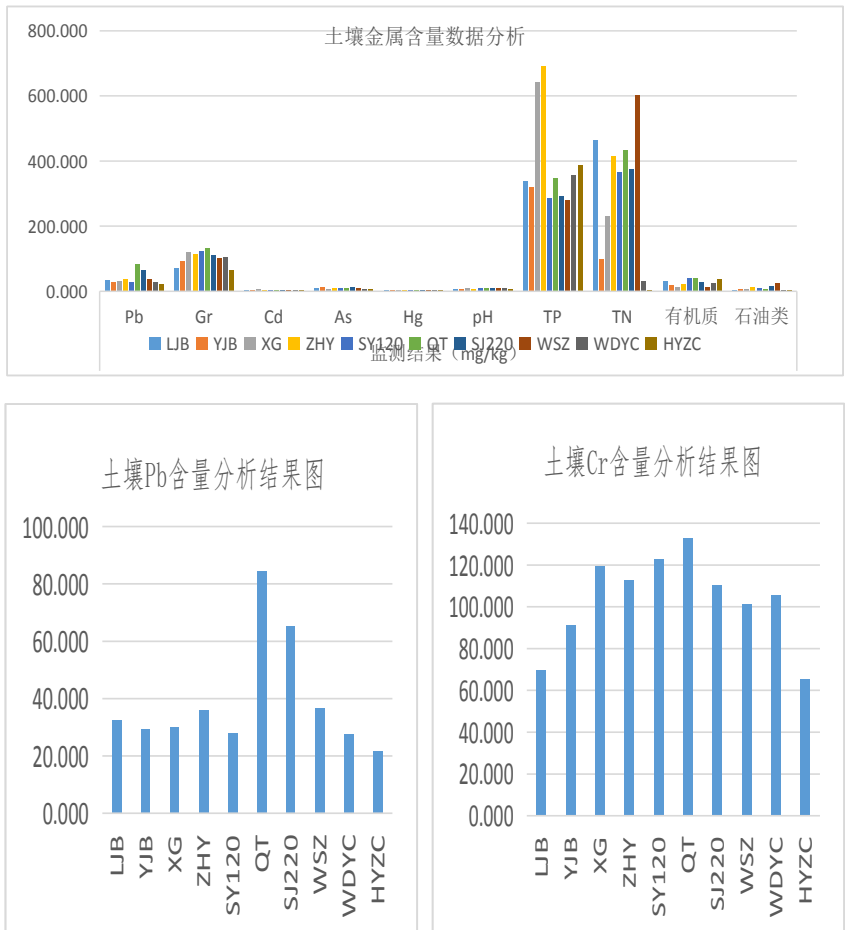
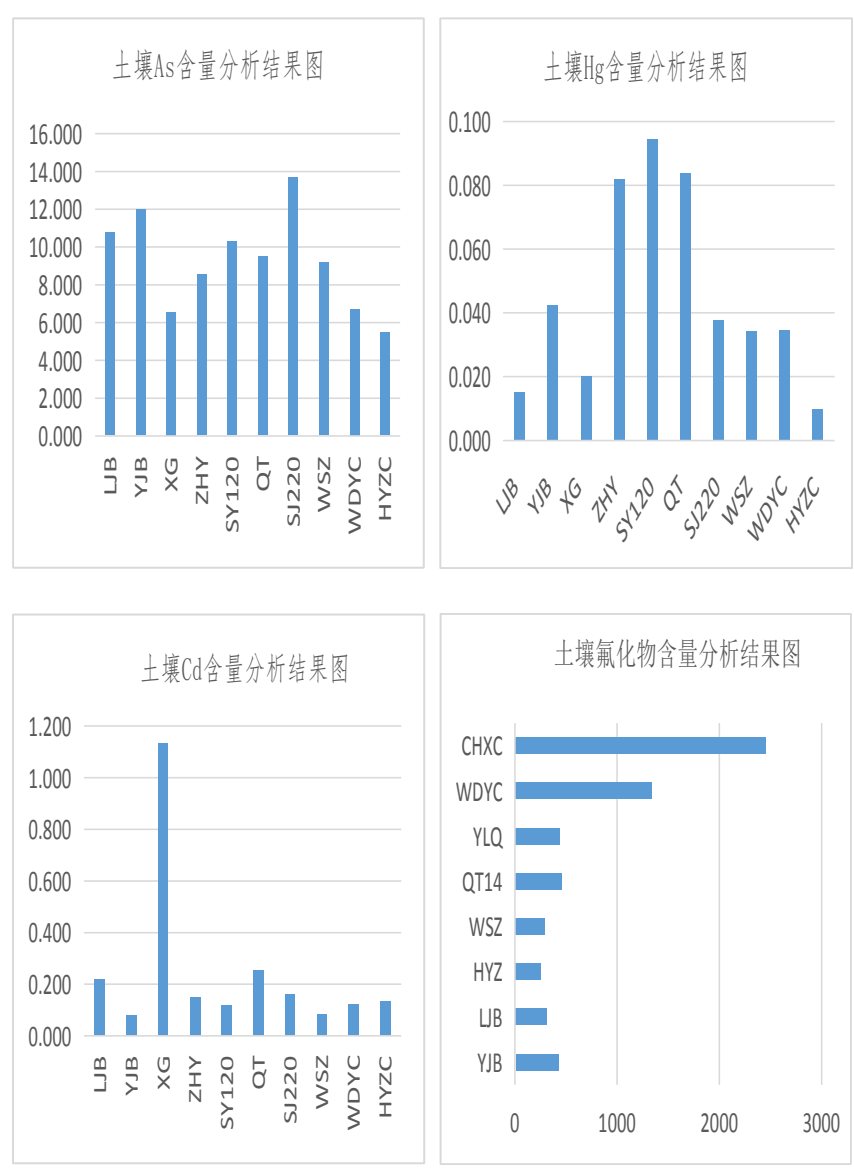

2. 2 氟化物

厂区内氟化物监测值普遍较低, 未有明显规律; 而厂区外, 主导风向下 风向1500-2500m范围监测点位的氟化物含量较厂区内及周边土壤中的氟 化物高9.5倍。说明氟化物与大气沉降作用有明显关系。

\section{3 造成土壤环境污染的主要来源和原因}

根据对钢铁厂厂内及主导风向下风向的土壤监测布点检测数据规律, 氟化物的污染较高的土壤为厂区下风向1500-2500范围, 说明是由于随着 大气的沉降飘落导致, 因此, 主要来源来自烧结、焙烧等工序有组织废气沉 降; 而重金属的污染土壤主要集中在装置区附近, 说明重金属的污染来源 主要为堆场无组织扬尘、雨水淋溶, 废水的处理过程可能产生的泄漏。同 时大气沉降颗粒物也存在一定的影响。

4 主要对策措施建议 


\title{
黄泛平原沙土区水土保持存在问题浅析
}

\author{
王亮 ${ }^{1}$ 夏雨 ${ }^{2}$ \\ 1 泰州市姜堰区国土资源信息中心 2 泰州市自然资源和规划局姜堰分局 \\ DOI:10.32629/eep.v2i10.463
}

[ 摘 要] 黄泛平原沙土区分布面积广泛, 水保工作任务重, 开展黄泛平原沙土区水土保持研究具有重要的应用价值。本文针对黄泛平原沙土区 的特点,总结了现状存在问题,并对水土流失的危害进行分析,提出了本区水保工作的研究思路。

[关键词] 黄泛平原沙土区; 水土保持; 分析

\section{引言}

水和土是人类赖以生存的基本物质条件, 是发展农业生产的重要因素, 水土流失不仅导致土壤蓄水保土能力下降, 同时造成河流、水库淤积和水 环境的恶化。水土保持工作对于改善水土流失地区的农业生产条件, 减少 水、旱、风沙等灾害, 实现水土资源可持续利用均具有重要意义。在全面 建设小康社会、加快推进社会主义现代化建设的新时期, 水土保持的基础 地位和作用更加凸现。黄泛平原沙土区分布面积广泛, 开展黄泛平原沙土 区水土保持研究具有重要的应用价值。

\section{1 存在问题}

黄泛平原沙土区分布面积广泛, 水土流失类型为水力和风力侵蚀。暴 雨时, 雨滴击打沟坡、堤岸, 先是产生沿坡面的细沟侵蚀, 进而发展成为切 沟侵蚀, 严重危及沟坡堤岸安全。由于岸坡保护不合理, 河道边坡遭到耕作, 水蚀严重, 即导致边坡失稳, 又淤积河道, 导致行洪不畅。另外河坡的大面 积坉塌, 造成沿岸耕地损失, 有的已影响到居民的房间和生命财产。

此外, 人为因素破坏了滩地表面土体和植被, 不合理的种植方式、粗放 的取土行为、无序的林木采伐也加剧了水土流失。近年来虽然投入资金对 区内河道进行了疏浚和整治, 但管理还未完全到位, 翻耕扒种现象比较普 遍, 造成河坡表层松动, 加速了河道淤积。

\section{2 水土流失危害}

水土流失破坏地面完整, 降低土壤肥力, 造成土地硬石化、沙化, 影响 农业生产, 威胁城镇安全, 加剧干旱等自然灾害的发生、发展, 导致群众生 活贫困, 生产条件恶化, 阻碍经济、社会的可持续发展。

(1) 水土流失冲刷土地, 破坏良田, 导致土地资源减少。由于暴雨径流 冲刷, 沟壑面积越来越大, 坡面逐渐减小。水土流失带走大量的土壤, 使土 层变薄, 导致耕地减少。

(2) 水土流失剥蚀土壤, 导致土壤肥力减退。由于水土流失, 耕作层中 有机质得不到有效积累, 土壤肥力下降, 裸露坡地一经暴雨冲刷, 就会使含 腐殖质多的表层土壤流失, 造成土壤肥力下降。此外, 水土流失对土壤的物
理、化学性质以及农业生态环境也带来一系列不利影响, 它破坏土壤结构, 造成耕地表层结皮, 抑制了微生物活动, 影响作物生长发育和有效供水, 降 低了作物产量和质量, 导致土壤综合生产能力降低。

(3) 水土流失淤积河道, 导致减灾抗灾能力下降。由于上游流域水土流 失, 汇入河道的泥沙量增大, 当挟带泥沙的河水流经中、下游河床、水库、 河道, 流速降低时, 泥沙就逐渐沉降淤泥, 使得水库淤浅而减小容量, 河道 阻塞而缩短通航里程, 严重影响水利工程和航运事业。此外, 还会带来河道 的淤积, 致使引水排水能力及减灾抗灾能力下降, 加剧洪涝灾害的发生, 严 重制约地方经济和社会的全面发展。

(4) 水土流失致使水质安全受到威胁, 生产生活受到影响。土壤中的有 机质及残存的农药和化肥等物质通过地面径流的冲刷随土壤一起带入水 体, 加剧水环境面源污染。据试验研究表明, 部分地区施用农药流失量大于 $50 \%$, 使用肥料当地利用率低于 $30 \%$, 主要进入土壤和水体造成面源污染, 影 响水质安全和食品安全, 给人民生产和生活带来一定的影响。

(5) 水土流失致使生态失调, 环境退化。本区生态环境资源比较丰富, 生态旅游业天然禀赋良好。但是, 水土流失造成部分地区基岩裸露、坡面 沟壑、河流湖泊浑浊、生物群落结构和湿地资源的破坏, 影响整个生态系 统的平衡, 在一定程度上制约生态旅游的发展。

\section{3 水土保持研究思路及必要性分析}

3.1 水土保持是生态文明建设的根本保障

党的十八届三中全会明确提出了包括生态文明在内的 “五位一体” 中 国特色社会主义建设总体布局, 要求把生态文明建设放在突出地位。因此, 水土保持必须坚持 “天人合一, 人与自然和谐相处” 的理念 ${ }^{[1]}$, 尊重自然, 充分发挥生态自然修复作用, 实现生态文明社会的可持续发展。

目前, 区内产业规划布局确定了果品、瓜菜、水产等特色产业, 同时规 划建设高标准农田项目区, 疏通和加固灌溉渠道, 通过农田配套水系工程建 设, 促进传统粗放的农业生产方式向高效集约化经营转变, 提高了农业综合 生产能力, 进而为大面积退耕还林、恢复植被、改善生态创造了条件。果园
对于历史遗留问题, 对应的土壤使用功能可做以调整, 已被污染的土 壤根据污染程度和使用功能进行相应的修复。

含量较高而不超标的土壤不适宜作为农田种植使用, 可作为工业用地 使用, 超标土壤应进行修复处理。同时根据大气沉降的影响规律, 钢厂常年 主导风向下风向不宜规划居民及农田。

\section{5 结束语}

综上所述, 随着社会的发展进步, 国民环保意识在不断增强, 社会各界 愈来愈重视环保工作和环境质量。为了提高我们的生活环境质量, 防止工 业化对环境带来的负面影响进一步恶化, 再加强钢铁行业的废气污染控制 同时, 我们可以根据现状规律情况进行合理利用和修复, 在不断发展工业
同步改善环境质量, 并同时以获取准确的环境监测数据, 为环境质量的监 控和规划提供有效的数据支持, 更好地开展环境保护工作, 提升生态环境 的质量。

\section{[参考文献]}

[1]王月华.钢铁企业对土壤和地下水的污染影响研究 [J].环境科学与 管理,2015(40):11.

[2]倪刘健,张甘霖,杨金玲等.钢铁工业区沉降对周边土壤的影响 [J]. 土壤学报,2007(44):4.

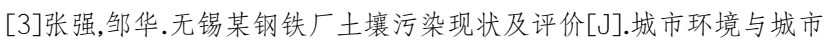
生态,2012(25):6. 